\title{
Circadian clock components RORa and Bmal1 mediate the anti-proliferative effect of MLN4924 in osteosarcoma cells
}

\author{
Shuju Zhang ${ }^{1}$, Jiaming Zhang ${ }^{1}$, Zhiyuan Deng ${ }^{2}$, Huadie Liu ${ }^{1}$, Wei Mao ${ }^{1}$, Fang Jiang ${ }^{1}$, \\ Zanxian Xia ${ }^{1}$, Jia-Da $\mathbf{L i}^{1}$ \\ ${ }^{1}$ The State Key Laboratory of Medical Genetics and School of Life Sciences, Central South University, Changsha, Hunan \\ 410078, China \\ ${ }^{2}$ Xiangya Stomatological Hospital, Central South University, Changsha, Hunan 410078, China
}

Correspondence to: Jia-Da Li, email: lijiada@sklmg.edu.cn

Keywords: MLN4924, osteosarcoma, RORa, Bmall, neddylation

Received: May 03, $2016 \quad$ Accepted: August 24, $2016 \quad$ Published: September 01, 2016

\section{ABSTRACT}

The anticancer small molecule MLN4924, a Nedd8-activating enzyme (NAE) inhibitor, triggers cell-cycle arrest, apoptosis, and senescence in cancer cells. In this study, we demonstrate that MLN4924 suppresses osteosarcoma cell proliferation by inducing G2/M cell cycle arrest and apoptosis. Our results indicate that MLN4924 stabilizes the retinoid orphan nuclear receptor alpha (RORa) by decreasing its ubiquitination. RNA interference of RORa attenuates the anti-proliferative effect of MLN4924 in U2OS osteosarcoma cells. MLN4924 up-regulates the expression of p21 and Bmal1, two transcriptional targets of RORa. However, p21 plays a minimal role in the anti-proliferative effect of MLN4924 in U2OS osteosarcoma cells. In contrast, Bmal1 suppression by siRNA attenuates the anti-proliferative effect of MLN4924 in U20S osteosarcoma cells, indicating that the MLN4924-mediated cell growth inhibition is mediated by Bmal1. These results show MLN4924 to be a promising therapeutic agent for the treatment of osteosarcoma and suggest that MLN4924-induced tumor growth inhibition is mediated by the circadian clock components RORa and Bmal1.

\section{INTRODUCTION}

Osteosarcoma is the most common primary malignant bone tumor in children and adolescents. In the past four decades, osteosarcoma has been treated with neoadjuvant chemotherapy followed by surgical removal of the primary tumor, often followed by additional adjuvant chemotherapy after the surgery. Cis-platinum, doxorubicin, methotrexate and cyclophosphamide have been used most often to treat osteosarcoma. Nevertheless, the 5-year overall survival rate of osteosarcoma is one of the lowest in the pediatric cancers, i.e. $\sim 65 \%$ for localized tumor $[1,2]$. It is therefore necessary and urgent to identify new therapeutic strategies for osteosarcoma patients.

Nedd8 is a ubiquitin-like molecule of $\sim 8 \mathrm{kDa}$ that is covalently linked to a number of proteins by a process known as neddylation. The most well characterized substrates of Nedd 8 are the cullin proteins, the scaffold components of Cullin-Ring E3-ubiquitin Ligases (CRLs) that are responsible for ubiquitination of $20 \%$ of cellular proteins degraded through the ubiquitin-proteasome system [3]. MLN4924 (pevonedistat), a selective Nedd8 activating enzyme (NAE) inhibitor, is an anti-cancer drug currently in clinical trials [4, 5]. Treatment with MLN4924 can suppress the progression of a variety of tumors [6-14]. Various CRLs substrates have been proposed to mediate the anti-cancer effects of MLN4924 [5, 15-17].

In this study, we show that MLN4924 suppresses the proliferation of osteosarcoma cells, which may be mediated, at least partly, through the retinoid orphan nuclear receptor alpha $(\mathrm{ROR} \alpha)$.

\section{RESULTS}

MLN4924 suppresses growth and tumorigenicity of osteosarcoma cells

We first evaluated the effect of MLN4924 on cell proliferation in three osteosarcoma cell lines: MG63, Saos-2 and U2OS. As shown in Figure 1A-1C, one day of MLN4924 (3 $\mu \mathrm{M})$ treatment did not significantly change the cell growth; however, MLN4924 significantly 
inhibited the cell proliferation after two days treatment and thereafter. In U2OS cells, MLN4924 suppressed cell growth in a dose-dependent manner (Figure 1D).

We next determined the anti-tumor activity of MLN4924 in osteosarcoma cells in vivo. MLN4924 was administered to nude mice bearing MG63 xenografts; the tumors were weighted after 15 days of the treatment. As shown in Figure 1E and 1F, MLN4924 significantly decreased the growth of MG63 xenograft tumors.

To determine how MLN4924 affects the cell cycle, a flow cytometry analysis was performed in three osteosarcoma cell lines: MG63, Saos-2 and U2OS in the presence of MLN4924. As shown in Figure 2, after $24 \mathrm{~h}$ treatment with MLN4924 (1 $\mu \mathrm{M})$, cells began to accumulate in G2/M phase. At $48 \mathrm{~h}$ after MLN4924 treatment, the cells with more than 4 chromosomes $(\geq 4$ $N$ DNA content) were significantly increased; this was similar to the MLN4924 effect in HCT116 cells [5].

A

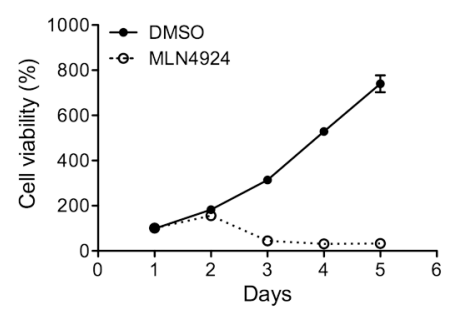

C

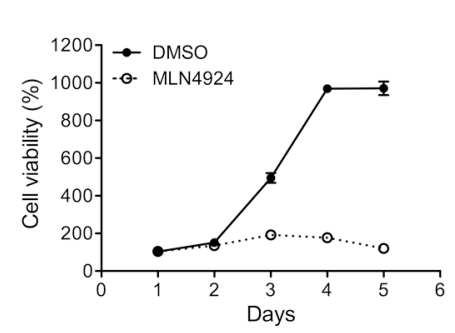

$E$

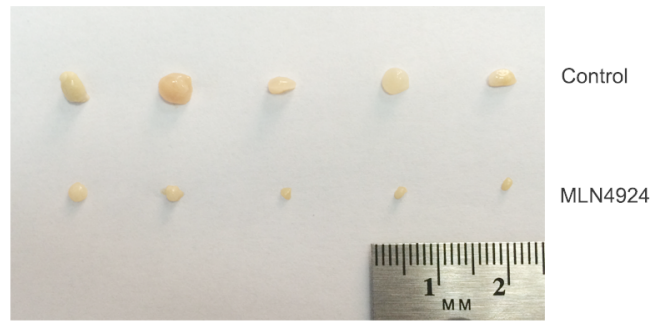

We also investigated the apoptotic effect of MLN4924 in the osteosarcoma cell lines. After labelling with Annexin V-FITC/PI, a flow cytometry was performed to analyze the apoptotic cells. As shown in Figure 3, treatment with MLN4924 $(1 \mu \mathrm{M})$ for $48 \mathrm{~h}$ induced significant apoptosis in MG63 and Saos-2 cells, but not in U2OS cells. (Apoptotic cells: MG63, DMSO: 5.37\% \pm 0.29, MLN4924: 33.60\% \pm 4.90, $P=0.003$; Saos-2, DMSO: $5.08 \% \pm 0.89$, MLN4924: $37.89 \% \pm$ 2.07, $P=0.004$; U2OS, DMSO: $5.60 \% \pm 1.81$, MLN4924: $6.10 \% \pm 1.25, P=0.84$, Figure 3D)

\section{MLN4924 increases stability of RORa}

The retinoid orphan nuclear receptor alpha $(\mathrm{ROR} \alpha)$ is an orphan nuclear receptor that regulates gene expression by binding to the ROR response elements (RORE). Recent studies indicate that $\mathrm{ROR} \alpha$ functions as

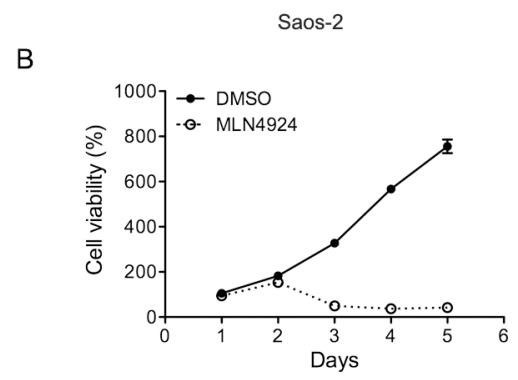

D

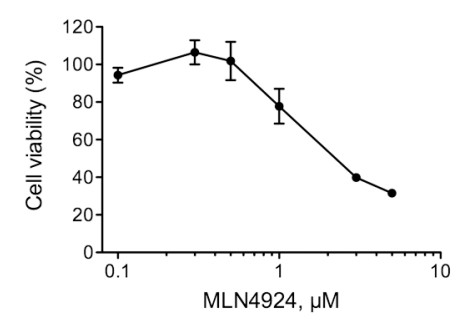

$\mathrm{F}$

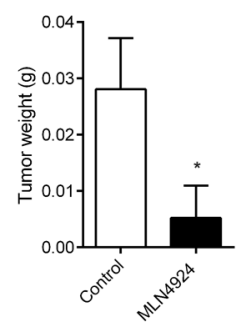

Figure 1: MLN4924 inhibits cell growth and tumorigenicity of osteosarcoma cells. A-C. Three osteosarcoma cell lines: MG63, Saos-2 and U2OS were treated with MLN4924 $(3 \mu \mathrm{M})$ or DMSO. Cell viability was assessed by an MTT assay. Each value is the mean \pm SEM of three replicates from a single assay. D. U2OS cells were treated with various concentrations of MLN4924 for $48 \mathrm{~h}$. Cell viability was assessed by MTT assay. E. MLN4924 significantly inhibited the growth of MG63 cells xenografts in vivo. $1 \times 10^{6}$ MG63 cells were injected subcutaneously into the flanks of nude mice. Ten days later, mice were treated with vehicle (control) or MLN4924 (30 mg/kg i.p.) twice a day for 3 days, and then 2 days without treatment for 15 days. F. Tumor weights after 15 days of treatment. $* P<0.05$, unpaired $t$ test. 
a tumor suppressive molecule [18]. Interestingly, ROR $\alpha$ is degraded by the DCAF1/DDB1/CUL4 E3 ubiquitin ligase complex $[19,20]$, which might be inhibited by MLN4924. We have therefore reasoned that ROR $\alpha$ may mediate the effect of MLN4924.

To investigate whether MLN4924 affects the degradation of $\operatorname{ROR} \alpha$, we first examined the endogenous ROR $\alpha$ protein levels in osteosarcoma cells treated $24 \mathrm{~h}$ with MLN4924. As shown in Figure 4A-4C, ROR $\alpha$ was significantly up-regulated in osteosarcoma MG63, Saos-2, and U2OS cells after MLN4924 (1 $\mu \mathrm{M})$ treatment.
To further investigate if MLN4924 affects the stability of ROR $\alpha$, U2OS cells transiently expressing Flag-labelled ROR $\alpha$ (Flag-ROR $\alpha$ ) were treated $24 \mathrm{~h}$ with MLN4924 ( $1 \mu \mathrm{M})$ or DMSO. 48 hours after transfection, cells were incubated $0,3,6,9$, and $12 \mathrm{~h}$ with cycloheximide $(\mathrm{CHX})$ to inhibit new protein synthesis, and ROR $\alpha$ protein levels were analyzed. As shown in Figure 4D and 4E, MLN4924 significantly prolonged the half life of ROR $\alpha$. Without MLN4924, the half life of ROR $\alpha$ was about $7 \mathrm{~h}$, whereas only about $20 \%$ of ROR $\alpha$ was degraded after $12 \mathrm{~h}$ in the presence of MLN4924.
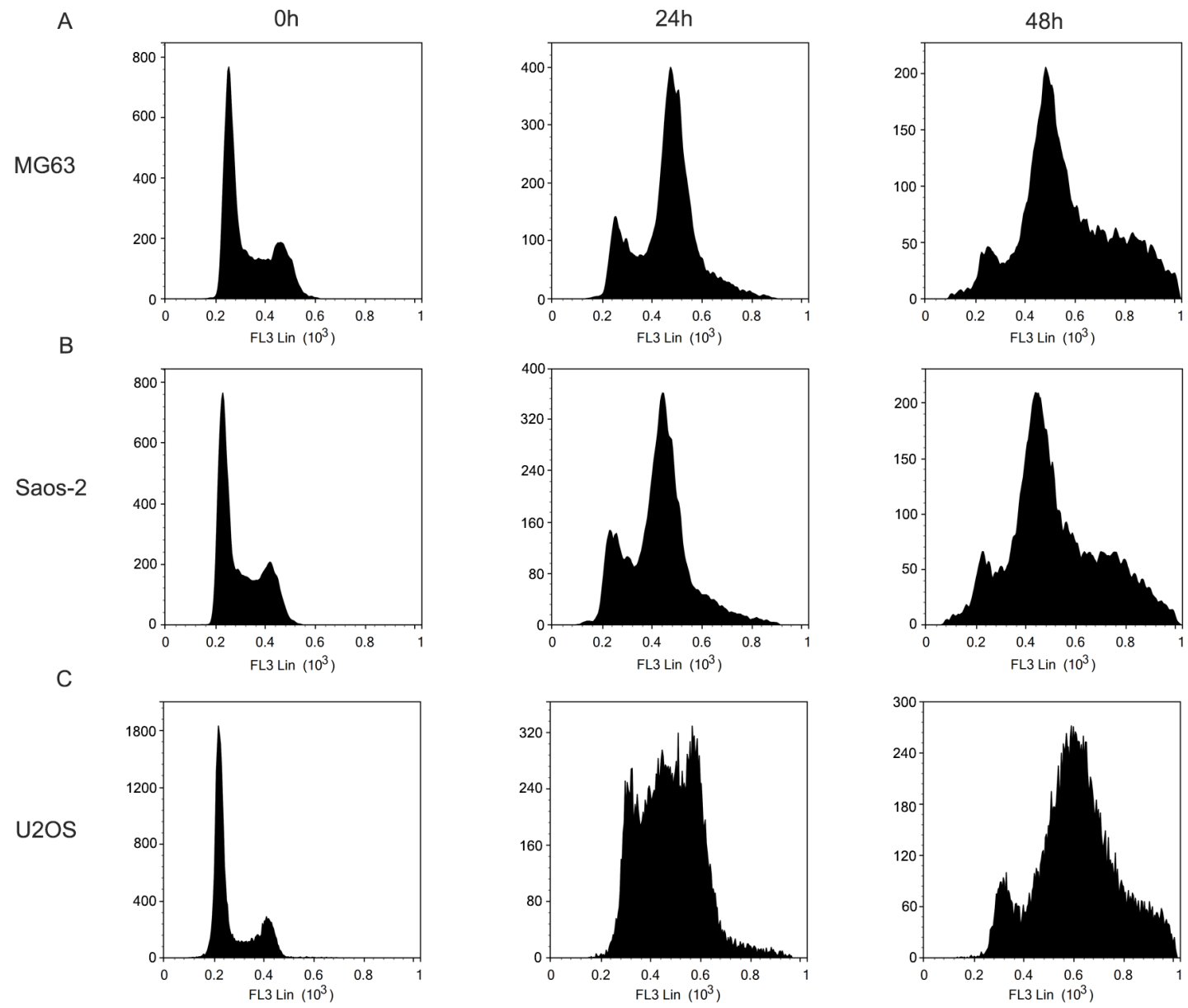

D

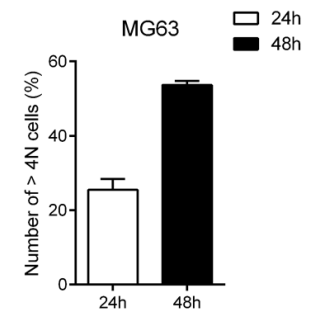

E

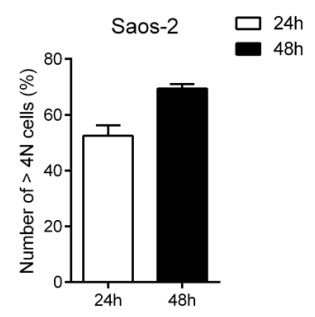

F

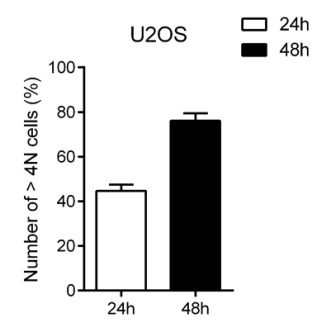

Figure 2: MLN4924 causes G2/M cell cycle arrest in osteosarcoma cells. Three osteosarcoma cell lines: MG63 A., Saos-2 B. and U2OS C. were treated with DMSO or MLN4924 $(1 \mu \mathrm{M})$ for 24 and $48 \mathrm{~h}$. Cells were harvested and fixed in ice-cold $70 \%$ ethanol overnight at $-20{ }^{\circ} \mathrm{C}$, and then stained with PI $(5 \mu \mathrm{g} / 100 \mu \mathrm{L})$ for $30 \mathrm{~min}$ at $4{ }^{\circ} \mathrm{C}$ in the dark. DNA profiles were analyzed by flow cytometry. $>4 N$ cells were shown in D-F. Each value was the mean \pm SEM of three replicates from a single assay. 
Next, we studied the effect of MLN4924 on the ubiquitination of ROR $\alpha$. U2OS cells co-expressing Flag-ROR $\alpha$ and HA-tagged uniquitin (HA-Ub) were treated with MLN4924 $(1 \mu \mathrm{M})$ or DMSO at $24 \mathrm{~h}$ after transfection. Cells were incubated $8 \mathrm{~h}$ with proteasome inhibitor MG-132 (10 $\mu \mathrm{M}) 48 \mathrm{~h}$ after transfection, and immunoprecipitation was performed. The anti-Flag antibody was used to pulldown Flag-ROR $\alpha$ proteins, and ubiqutination was detected with the anti-HA antibody. As shown in Figure $4 \mathrm{~F}$ and $4 \mathrm{G}$, the ubiquitination of ROR $\alpha$ was decreased by about $70 \%$ in the presence of MLN4924.

\section{Suppression of ROR $\alpha$ attenuates MLN4924- induced cell cycle arrest}

To determine whether MLN4924 acts through $\mathrm{ROR} \alpha$ to suppress cell growth, U2OS osteosarcoma cells were transfected with two distinct ROR $\alpha$-specific siRNAs
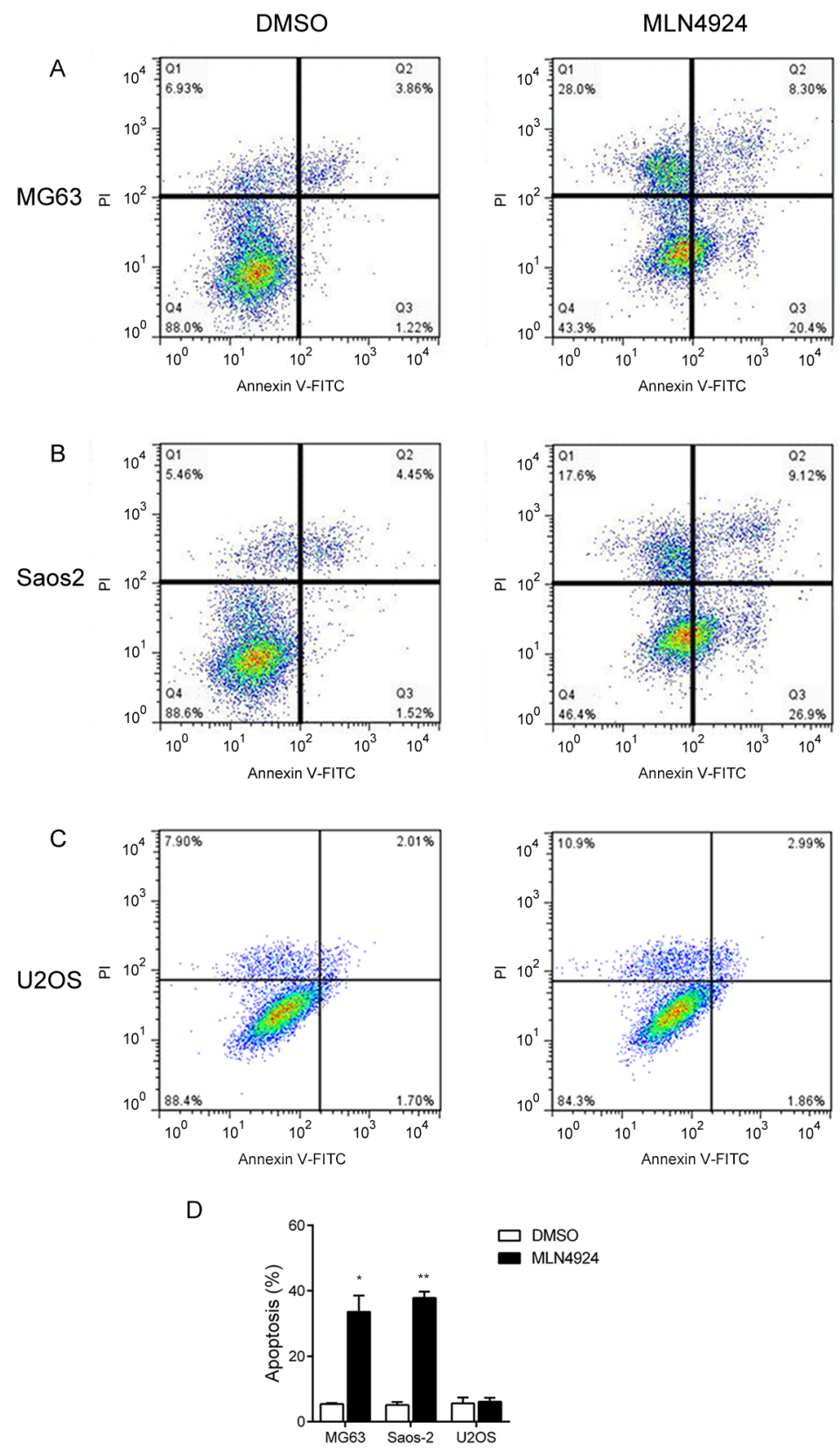

Figure 3: MLN4924 induces apoptosis in MG63 and Saos-2, but not U2OS cells. A-C. Three osteosarcoma cell lines MG63 (A), Saos-2 (B) and U2OS (C) were treated with DMSO or MLN4924 (1 $\mu \mathrm{M})$ for $48 \mathrm{~h}$. Cells were harvested and stained with Annexin V-FITC and PI for $20 \mathrm{~min}$ in the dark. Apoptosis was analyzed by flow cytometry. D. The graph illustrates the percentage of total apoptosis cells. Each value was the mean \pm SEM of three replicates from a single assay. Q1: live cells (annexin V-/PI), Q2: early apoptotic cells (annexin $\mathrm{V}^{+} / \mathrm{PI}$ ), Q3: late apoptotic cells (annexin $\mathrm{V}^{+} / \mathrm{PI}^{+}$) and Q4:necrotic cells (annexin $\mathrm{V}^{-} / \mathrm{PI}^{+}$). ${ }^{*} P<0.05,{ }^{*} P<0.01$ unpaired $t$ test. 
(Figure 5A). The cells were treated 48 and $72 \mathrm{~h}$ with MLN4924 $(3 \mu \mathrm{M})$ or DMSO at $48 \mathrm{~h}$ after transfection, and the cell proliferation was monitored with an MTT assay. Compared with cells transfected with a negative control siRNA, MLN4924 was significantly less effective in suppressing the growth of ROR $\alpha$-depleted cells (Cell viability: $48 \mathrm{~h}$, Control: $76.74 \% \pm 1.72$, ROR $\alpha$-siRNA-1: $92.62 \% \pm 0.76, P<0.0001$, ROR $\alpha$-siRNA-2: $100.0 \% \pm 1.69$, $P<0.0001 ; 72$ h, Control: $67.08 \% \pm 0.80$, ROR $\alpha$-siRNA-1: $83.12 \% \pm 1.39, P<0.0001$, ROR $\alpha$-siRNA-2: $79.47 \% \pm 1.97$, $P<0.0002$, Figure 5B).

To further examine whether $\operatorname{ROR} \alpha$ participated in MLN4924-induced cell cycle arrest, flow cytometry analysis was performed on U2OS cells transfected with control or ROR $\alpha$-specific siRNA-1 after MLN4924 (1 $\mu \mathrm{M})$ treatment for 0, 24 and $48 \mathrm{~h}$. As shown in Figure 5C-5D,
ROR $\alpha$ suppression significantly attenuated the G2/M cell cycle arrest after $48 \mathrm{~h}$ treatment, as illustrated with percentage of cells at $>4 N$ stages $(24 \mathrm{~h}$, Control: $10.91 \% \pm$ 1.50, ROR $\alpha$-siRNA: $5.61 \% \pm 0.18, P=0.33 ; 48$ h, Control: $53.47 \% \pm 0.80, \mathrm{ROR} \alpha$-siRNA: $31.95 \% \pm 2.95, P=0.02)$.

\section{p21 minimally affects the MLN4924-induced cell growth suppression}

Next, we investigated the downstream molecules of ROR $\alpha$ involved in the MLN4924 anti-cancer effect. ROR $\alpha$ is a putative transcription factor for cyclin-dependent kinase (CDK) inhibitor p21WAF1/CIP1. Indeed, RNAi of ROR $\alpha$ resulted in downregulation of p21 (Figure 6A). In addition, p21 was up-regulated in osteosarcoma cells MG63, Saos-2, and U2OS after MLN4924 (1 $\mu \mathrm{M})$ treatment (Figure 6B-6D).

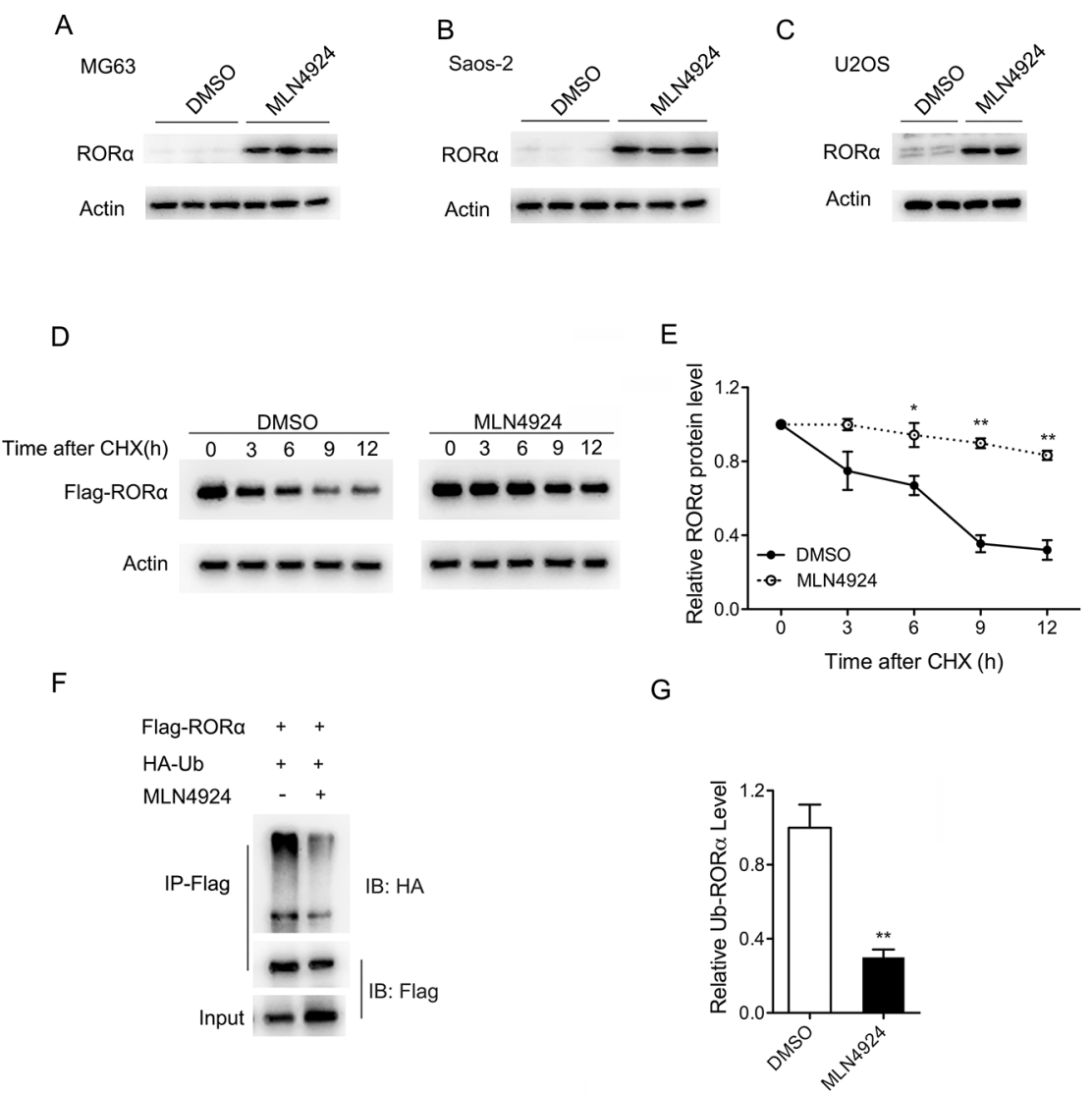

Figure 4: MLN4924 increases the stability of ROR $\alpha$. A-C. The endogenous ROR $\alpha$ protein levels detected with Western blot after treatment with MLN4924 (1 $\mu \mathrm{M})$ or DMSO in MG63 (A), Saos-2 (B) and U2OS (C) cells for 24 h. D. MLN4924 increased the half-life of ROR $\alpha$. U2OS cells were transiently transfected with plasmids expressing the Flag-ROR $\alpha$. At $24 \mathrm{~h}$ after transfection, MLN4924 (1 $\mu \mathrm{M})$ or DMSO were added into respective cell culture media. $24 \mathrm{~h}$ later, cells were treated with cycloheximide (CHX) for $0,3,6,4,9$ and $12 \mathrm{~h}$. Equal amounts of whole cell lysates were analyzed by Western blot with a Flag antibody (M2). Actin was used as an internal control. E. The graph illustrates the quantification of ROR $\alpha$ by densitometry of triplicate experiments (mean $\pm \mathrm{SEM}$ ). ${ }^{*} P<0.05, * * P<0.01$ by post hoc Bonferroni $t$ test. F. MLN4924 decreased the ubiquitination of ROR $\alpha$. Flag-ROR $\alpha$ and HA-Ub expression plasmids were transiently transfected into U2OS cells. At $24 \mathrm{~h}$ after transfection, MLN4924 $(1 \mu \mathrm{M})$ or DMSO were added into respective cell culture media. $24 \mathrm{~h}$ later, cells were treated with MG132 for $8 \mathrm{~h}$. Equal amounts of whole cell lysates were used for immunoprecipitation (IP). The protein immunoprecipitated by Flag antibody was analyzed by Western blot with HA or Flag antibody. G. The graph illustrates the quantification of ubiquitinated ROR $\alpha$ by densitometry of triplicate experiments (mean $\pm \mathrm{SEM}$ ). $* * P<0.01$ by unpaired $t$ test. 
To determine whether p21 is involved in the MLN4924-induced cell growth suppression, U2OS cells were transfected with two distinct p21-specific siRNAs (Figure 6E). Although both siRNAs significantly decreased the p21 levels, no significant effect was observed on the cell growth suppression elicited by MLN4924 (3 $\mu \mathrm{M})$ (Cell viability: $48 \mathrm{~h}$, Control: 63.32\% \pm 2.41, p21-siRNA-1: $57.68 \% \pm 1.74, P=0.071, \mathrm{p} 21-$ siRNA-2: $58.80 \% \pm 1.34, P=0.11 ; 72 \mathrm{~h}$, Control: $47.60 \%$ \pm 0.89, p21-siRNA-1: $47.10 \% \pm 0.82, P=0.68, \mathrm{p} 21-$ siRNA-2: $44.35 \% \pm 1.59, P=0.08$, Figure $6 \mathrm{~F}$ ).

Then, we performed flow cytometry analysis of U2OS cells transfected with control or p21-specific siRNA-1 after MLN4924 $(1 \mu \mathrm{M})$ treatment for 0,24 and $48 \mathrm{~h}$. As shown in Figure $6 \mathrm{G}$ and $\mathrm{H}$, p21 suppression had a minimal effect on the MLN4924-induced G2/M accumulation and increase in the $>4 N$ cells $(24 \mathrm{~h}$, Control: $25.01 \% \pm 1.29$, p21-siRNA: $16.87 \% \pm 1.65, P=0.06 ; 48$ h, Control: $61.84 \% \pm 1.71$, p21-siRNA: $54.16 \% \pm 0.25, P=0.05)$.

A

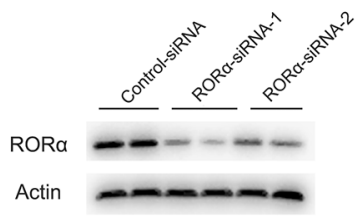

C
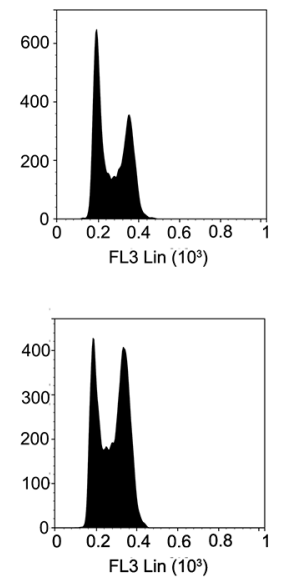

$24 h$
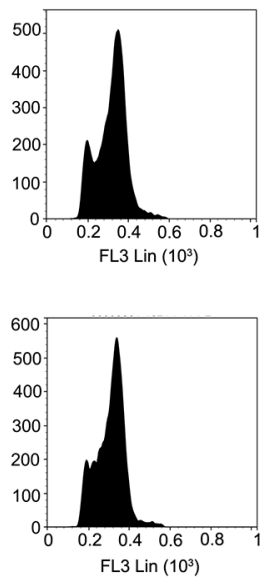

\section{MLN4924 increases Bmal1 expression at the transcriptional level}

ROR $\alpha$ induces the expression of Bmal1, the essential component of circadian clock. As expected, RNAi of ROR $\alpha$ resulted in downregulation of Bmall in the absence or presence of MLN4924 (Figure 6A and Supplementary Figure S1). Recently, Bmal1 has been demonstrated to suppress cell growth through G2/M cell cycle arrest [21-24], suggesting that Bmall functions downstream of the MLN4924-ROR $\alpha$ pathway.

To investigate the role of Bmall in the anti-cancer effect of MLN4924, we first examined the endogenous Bmal1 protein levels after MLN4924 (1 $\mu \mathrm{M}, 24 \mathrm{~h}$ ) treatment in osteosarcoma cell lines. As shown in Figure 7A-7C, Bmal1 was significantly up-regulated in osteosarcoma cells MG63, Saos-2, and U2OS after MLN4924 treatment. In U2OS osteosarcoma cells, Bmall protein levels were induced by MLN4924

B

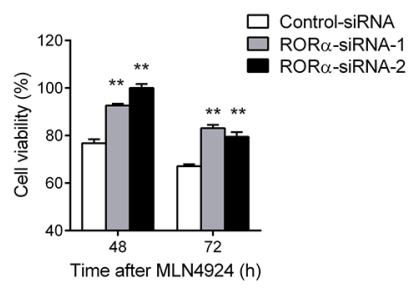

$48 \mathrm{~h}$
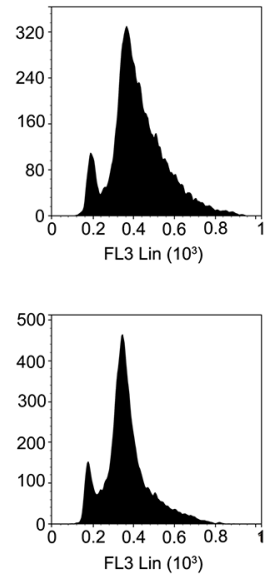

D

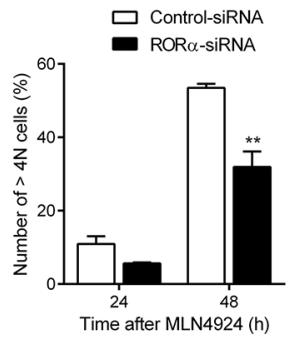

Figure 5: Down-regulation of ROR $\alpha$ attenuates MLN4924-induced cell growth suppression. A. U2OS osteosarcoma cells were transfected with two distinct ROR $\alpha$-specific siRNAs or a negative control siRNA. $72 \mathrm{~h}$ after transfection, whole cell lysates were analyzed with Western blot using an antibody against ROR $\alpha$. B. U2OS cells were treated with MLN4924 (3 $\mu$ M) or DMSO for 48 h after transfection with ROR $\alpha$-specific siRNAs or negative control siRNA, and the cell proliferation was monitored with an MTT assay at 48 and $72 \mathrm{~h}$ after MLN4924 treatment. Each value is the mean \pm SEM of three replicates from a single assay $(* * P<0.01$ by post hoc Bonferroni $t$ test). C. U2OS cells transfected with ROR $\alpha$-specific siRNA or negative control siRNA after MLN4924 (1 $\mu$ M) treatment for 0, 24 and $48 \mathrm{~h}$. Cells were harvested and fixed in ice-cold $70 \%$ ethanol overnight at $-20^{\circ} \mathrm{C}$, then stained with PI $(5 \mu \mathrm{g} / 100 \mu \mathrm{L})$ for $30 \mathrm{~min}$ at $4{ }^{\circ} \mathrm{C}$ in the dark. DNA profiles were analyzed by flow cytometry. D. The graph illustrates the percentage of $>4 N$ cell of four replicates from a single assay (**P< 0.01 by post hoc Bonferroni $t$ test). 
in a concentration-dependent manner. (Figure 7D). Nevertheless, MLN4924 did not influence the half-life and ubiquitination of Bmall protein (Figure 7E-7G).

We therefore examined the effect of MLN4924 on Bmal1 transcription. As shown in Figure 7H, MLN4924 (1 $\mu \mathrm{M})$ significantly up-regulated the mRNA level of Bmal1. We further examined the effect of MLN4924 on the rhythmic expression of Bmal1. U2OS cells were synchonization with dexamethasone in the presence or absence of MLN4924 ( $1 \mu \mathrm{M})$, and then harvested every $4 \mathrm{~h}$ beginning $24 \mathrm{~h}$ after synchonization. In the absence of MLN4924, Bmal1 expression showed a circadian rhythm, peaking at $36 \mathrm{~h}$ after snchronization. MLN4924 disrupted the circadian rhythm; Bmall expression was increased in all time points in the presence of MLN4924 (Figure 7I). It should be noted that both ROR $\alpha$ mRNA and protein levels were significantly elevated under synchronized conditions (Supplementary Figure S2).

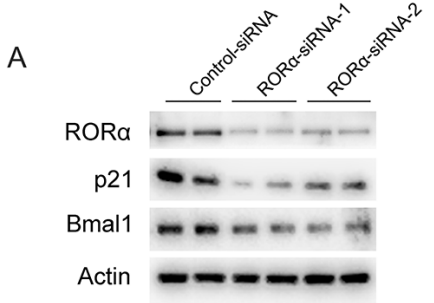

E

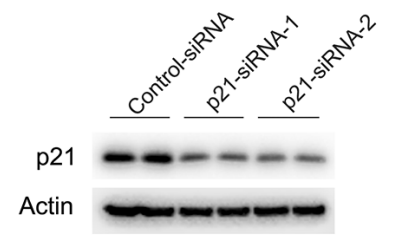

C

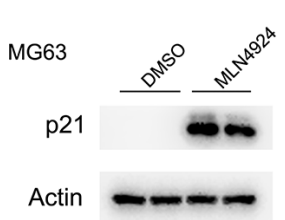

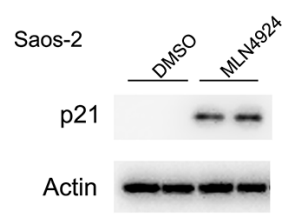

D

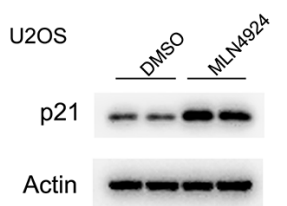

$\mathrm{F}$

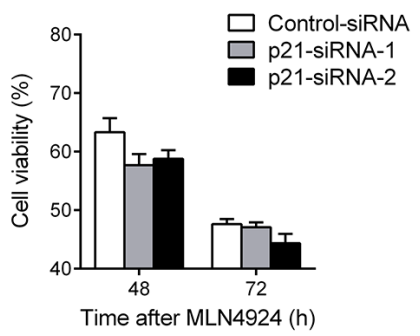

G
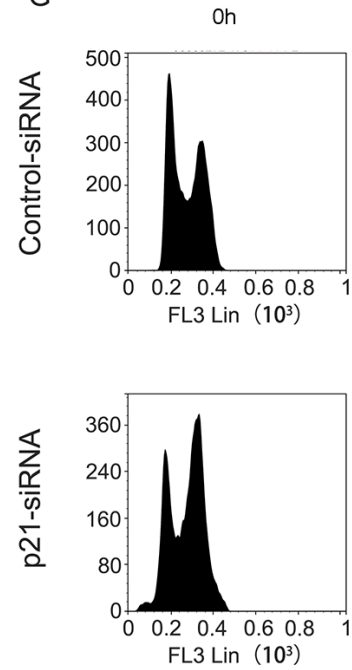

$24 \mathrm{~h}$
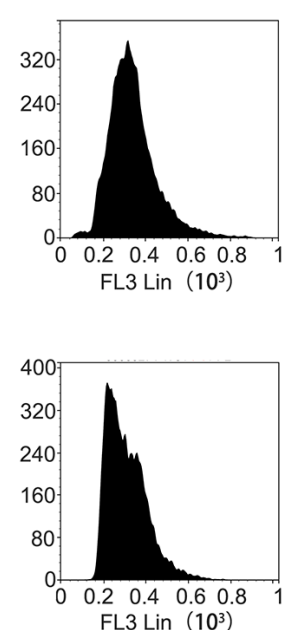

$48 \mathrm{~h}$
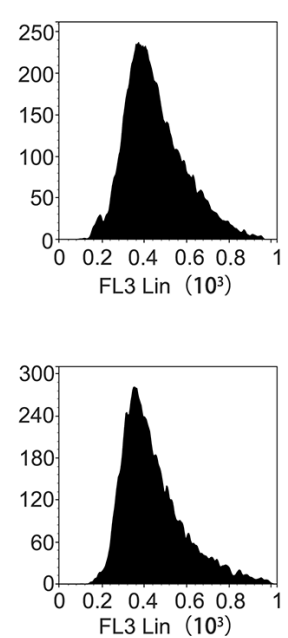

$\mathrm{H}$

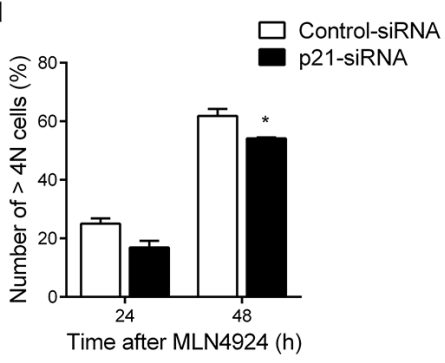

Figure 6: p21 minimally affects the MLN4924-induced cell growth inhibition. A. U2OS osteosarcoma cells were transfected with two distinct ROR $\alpha$-specific siRNAs or a negative control siRNA. $72 \mathrm{~h}$ after transfection, whole cell lysates were analyzed with Western blot using antibodies for ROR $\alpha$, p21, Bmal1 and actin, respectively. B-D. The endogenous p21 protein levels detected with Western blot after treatment with MLN4924 (1 $\mu$ M) or DMSO in MG63 (B), Saos-2 (C) and U2OS (D) cells for 24 h. E. U2OS osteosarcoma cells were transfected with two distinct $\mathrm{p} 21$-specific siRNAs or a negative control siRNA. $72 \mathrm{~h}$ after transfection, whole cell lysates were analyzed with Western blot using an antibody against p21. F. U2OS cells were treated with MLN4924 $(3 \mu \mathrm{M})$ or DMSO from $48 \mathrm{~h}$ after transfection with p21-specific siRNA or negative control siRNA, and the cell proliferation was monitored with an MTT assay at 48 and $72 \mathrm{~h}$ after MLN4924 treatment. Each value is the mean \pm SEM of three replicates from a single assay. G. U2OS cells transfected with p21-specific siRNA or negative control siRNA after MLN4924 (1 $\mu \mathrm{M})$ treatment for 0, 24 and $48 \mathrm{~h}$. Cells were harvested and fixed in ice-cold $70 \%$ ethanol overnight at $-20{ }^{\circ} \mathrm{C}$, then stained with PI $(5 \mu \mathrm{g} / 100 \mu \mathrm{L})$ for $30 \mathrm{~min}$ at $4{ }^{\circ} \mathrm{C}$ in the dark. DNA profiles were analyzed by flow cytometry. (D) The graph illustrates the percentage of $>4 N$ cell of four replicates from a single assay ( ${ }^{P}<0.05$ by post hoc Bonferroni $t$ test). 


\section{Bmal1 participates in the MLN4924-induced cell growth inhibition}

To determine whether MLN4924 acts through Bmall to suppress cell growth, U2OS osteosarcoma cells were transfected with two distinct Bmal1-specific siRNAs (Figure 8A). The cells were treated 48 and $72 \mathrm{~h}$ with MLN4924 $(3 \mu \mathrm{M})$ or DMSO at $48 \mathrm{~h}$ after transfection, and the cell proliferation was monitored with an MTT assay. Compared with cells transfected with control siRNA,
MLN4924 was significantly less effective in suppressing the growth of Bmal1-depleted cells (cell viability: $48 \mathrm{~h}$, Control: $69.83 \% \pm 3.41$, Bmall-siRNA-1: $84.73 \% \pm 2.56$, $P=0.0013$, Bmal1-siRNA-2: $86.99 \% \pm 1.21, P<0.0001$; 72 h, Control: $56.37 \% \pm 3.98$, Bmall-siRNA-1: $69.57 \% \pm$ $0.99, P=0.0028$, Bmall-siRNA-2: $69.50 \% \pm 1.82$, $P=0.005$, Figure $8 \mathrm{~B})$.

We also overexpressed Bmall in U2OS cells, and the anti-proliferative efficacy of MLN4924 was analyzed with MTT assay. As shown in Figure 8C, overexpression
A

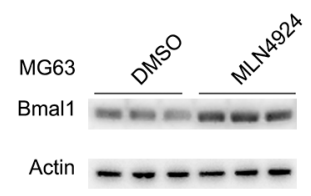

D

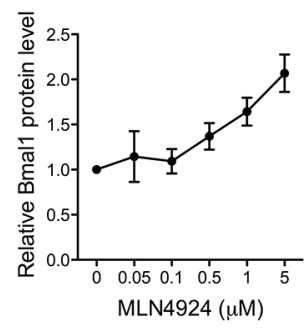

G

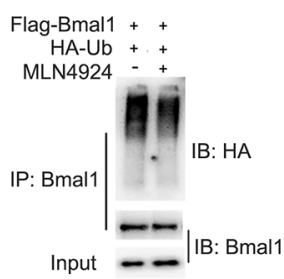

B

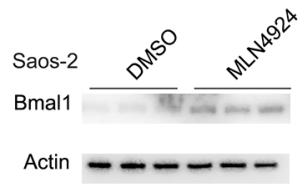

E

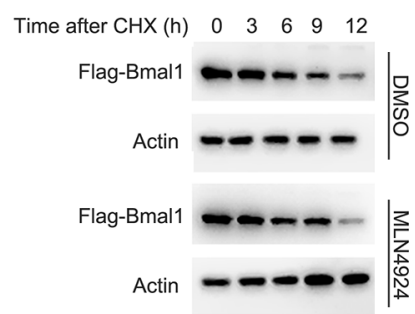

$\mathrm{H}$

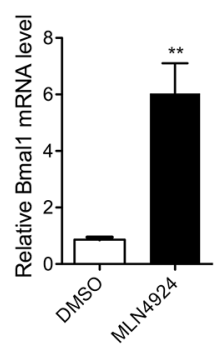

C

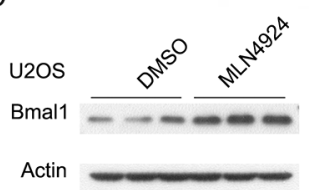

$\mathrm{F}$

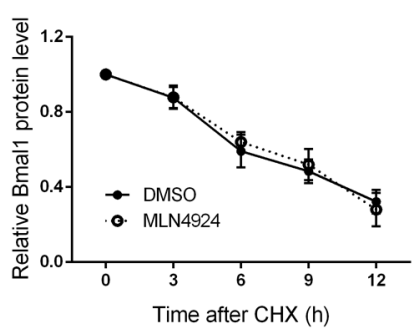

I

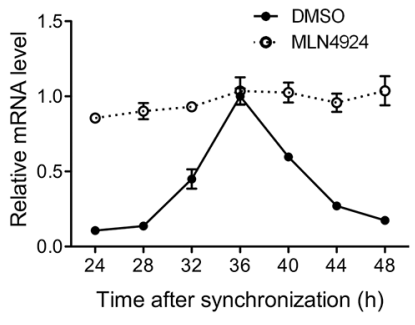

Figure 7: MLN4924 increases Bmal1 at the transcriptional level. A-C. The endogenous Bmal1 protein levels detected with Western blot after treatment with MLN4924 (1 $\mu \mathrm{M})$ or DMSO in MG63 (A), Saos-2 (B) and U2OS (C) cells for 24 h. D. U2OS cells treated with various concentration of MLN4924 for $24 \mathrm{~h}$. Whole cell lysates were analyzed by Western blot using an antibody against Bmal1. The densitometry of Bmal1 treated without MLN4924 was set as 1. Data from various concentration of MLN4924 are presented as fold of this level. E. MLN4924 did not influence the half-life of Bmal1. U2OS cells were transiently transfected with plasmids expressing Bmal1. At $24 \mathrm{~h}$ after transfection, MLN4924 $(1 \mu \mathrm{M})$ or DMSO were added into respective cell culture medium. $24 \mathrm{~h}$ later, cells were treated with cycloheximide (CHX) for 0, 3, 6, 9 and $12 \mathrm{~h}$. Equal amounts of whole cell lysates were analyzed by Western blot with a Flag antibody. Actin was used as an internal control. F. The graph illustrates the quantification of Bmall by densitometry of triplicate experiments (mean \pm SEM). G. MLN4924 did not influence the ubiquitination of Bmal1. Bmal1 and HA-Ub expression plasmids were transiently transfected into U2OS cells. At $24 \mathrm{~h}$ after transfection, MLN4924 or DMSO were added into respective cell culture medium. $24 \mathrm{~h}$ later, cells were treated with MG132 for $8 \mathrm{~h}$. Equal amounts of whole cell lysates were used for immunoprecipitation (IP). The protein immunoprecipitated by Bmal1 antibody was analyzed by Western blot with HA and Bmal1 antibody. H. MLN4924 increased the Bmal1 transcription. U2OS cells were treated with MLN4924 (1 $\mu \mathrm{M})$ or DMSO for $24 \mathrm{~h}$, and the total RNA was extracted. The Bmall mRNA level was examined with qPCR using specific primers. The expression of Bmal1 in cells treated with DMSO was set as 1. Data from MLN4924-treated cell were presented as fold of this level. Each value is the mean $\pm \mathrm{SEM}$ of three replicates from a single assay ( $* * P<0.01$ by unpaired $t$ test). I. U2OS cells were synchronized with dexamethasone in the presence of MLN4924 $(1 \mu \mathrm{M})$ or DMSO, and then harvested every $4 \mathrm{~h}$ beginning $24 \mathrm{~h}$ after synchronization. The Bmal1 mRNA level was examined with qPCR using specific primers. The expression of Bmall in cells treated with DMSO at $36 \mathrm{~h}$ was set as 1 . Data from other treatments were presented as fold of this level. Each value is the mean $\pm \mathrm{SEM}$ of three replicates form a single assay. Solid line, DMSO; dashed line, MLN4924. 
of Bmall significantly enhanced the effect of MLN4924 in both control and ROR $\alpha$-depleted U2OS cells. (Cell viability: Control: $74.80 \% \pm 1.88, \mathrm{ROR} \alpha-\mathrm{siRNA}$ : $84.40 \% \pm 3.17$, Control+Bmal1: $58.5 \% \pm 1.91$, ROR $\alpha-$ siRNA+Bmal1: $63.5 \% \pm 2.13$ ).

To further examine whether Bmall participates in MLN4924-induced cell cycle distribution, flow cytometry analysis was performed in U2OS cells transfected with control or Bmall-specific siRNA-1 after MLN4924 $(1 \mu \mathrm{M})$ treatment for 0,24 and $48 \mathrm{~h}$. As shown in Figure 8D-8E, Bmall depletion significantly attenuated the G2/M cell cycle arrest after $48 \mathrm{~h}$ treatment, as illustrated with percentage of cells at $>4 N$ stages ( 24 h, Control: $8.09 \% \pm 3.24$, Bmal1-siRNA: $6.12 \% \pm 1.33$, $P=0.63 ; 48$ h, Control: $46.89 \% \pm 0.13$, Bmall-siRNA: $26.96 \% \pm 0.75, P=0.0014)$.

\section{DISCUSSION}

In this study, we have shown that a Nedd8-activating enzyme inhibitor, MLN4924, suppresses proliferation of osteosarcoma cells through $\mathrm{G} 2 / \mathrm{M}$ cell cycle arrest and apoptosis. In addition, we have demonstrated that the circadian clock components $\operatorname{ROR} \alpha$ and Bmall play
A

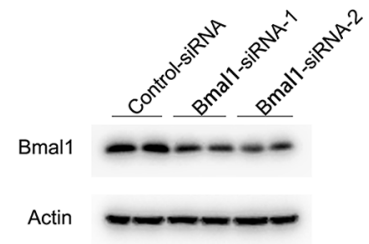

D
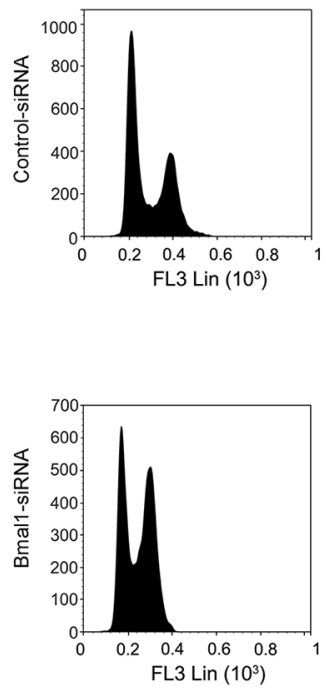

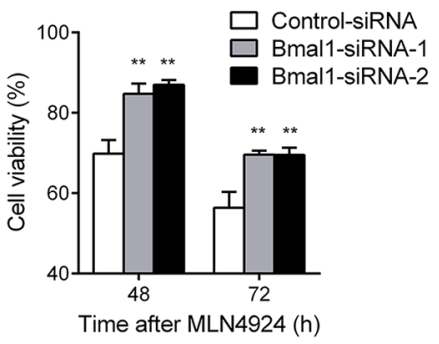

$24 h$
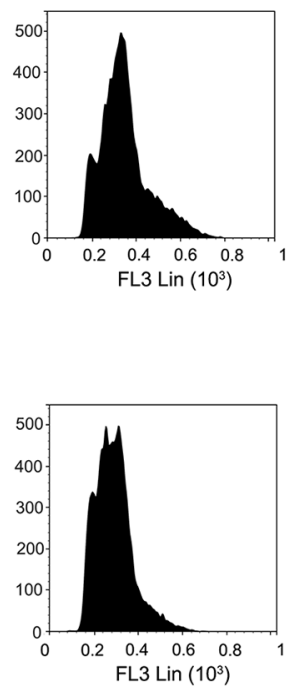

$48 \mathrm{~h}$
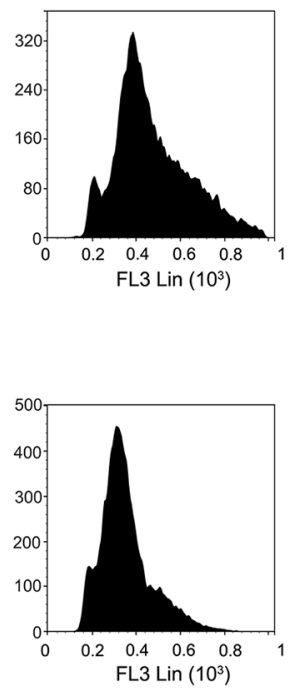

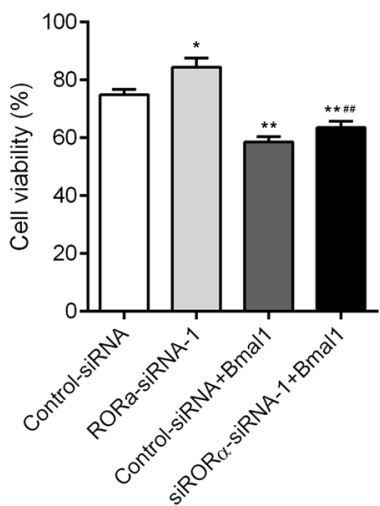

E

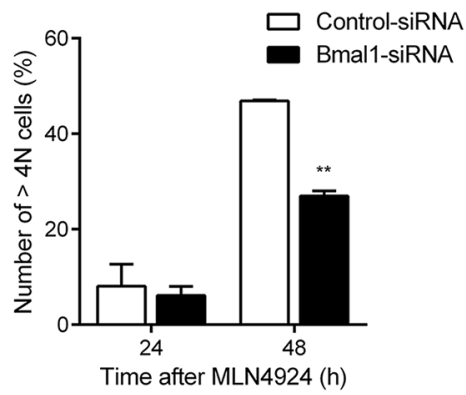

Figure 8: Bmal1 participates in the MLN4924-induced cell growth inhibition. A. U2OS osteosarcoma cells were transfected with two distinct Bmal1-specific siRNAs or a negative control siRNA. $72 \mathrm{~h}$ after transfection, whole cell lysates were analyzed by Western blot using an antibody against Bmal1. B. U2OS cells were treated with MLN4924 (3 $\mu \mathrm{M})$ or DMSO at $48 \mathrm{~h}$ after transfection with Bmal1specific siRNAs or negative control siRNA, and the cell proliferation was monitored with an MTT assay at 48 and $72 \mathrm{~h}$ after MLN4924 treatment. Each value is the mean \pm SEM of three replicates form a single assay. C. U2OS cells were treated with MLN4924 (3 $\mu$ M) or DMSO at $48 \mathrm{~h}$ after transfection with ROR $\alpha$-specific siRNA or/and Bmall-expressing plasmid, and the cell proliferation was monitored with MTT assay at $48 \mathrm{~h}$ after MLN4924 treatment. Each value is the mean \pm SEM of three replicates from a single assay. (* compared with control group; \# compared with ROR $\alpha$-siRNA-1 group. ${ }^{*} P<0.05,{ }^{*} P<0.01$, \#\#P<0.01 by post hoc Bonferroni $t$ test). D. U2OS cells transfected with Bmall-specific siRNA or negative control siRNA were treated with MLN4924 (1 $\mu$ M) for 0, 24 and 48 h. Cells were harvested and fixed in ice-cold $70 \%$ ethanol overnight at $-20{ }^{\circ} \mathrm{C}$, then stained with PI $(5 \mu \mathrm{g} / 100 \mu \mathrm{L})$ for 30 min at $4{ }^{\circ} \mathrm{C}$ in the dark. DNA profiles were analyzed by flow cytometry. $\mathbf{E}$. The graph illustrates the percentage of $>4 N$ cell of four replicates from a single assay $(* * P<$ 0.01 by post hoc Bonferroni $t$ test). 
important roles in the MLN4924 effect in osteosarcoma cells. MLN4924 stabilizes a cullin substrate ROR $\alpha$, which in turn transactivates Bmal1. Downregulation of ROR $\alpha$ or Bmal1 in U2OS osteosarcoma cells attenuates the MLN4924-induced cell growth suppression as well as G2/M cell cycle arrest.

Physiology and behavior are subjected to daily oscillations driven by an endogenous circadian clock. Disruption of the circadian rhythm may lead to a series of disorders, including cancer. A study that followed 78,562 nurses showed that the nurses who always worked night shift for at least thirty years had a significantly increased risk of breast cancer as compared with those who only worked during daylight [25-27]. Accumulative evidence has shown that Bmall and $\operatorname{ROR} \alpha$ are tumor suppressors. Jiang et al have demonstrated that Bmall level is downregulated in pancreatic cancer [21]. Bmall is transcriptionally silenced by promoter $\mathrm{CpG}$ island hypermethylation in hematologic malignancies, such as diffuse large B-cell lymphoma and acute lymphocytic and myeloid leukemia [28]. Overexpression of Bmall inhibits, whereas RNA interference of Bmall promotes tumor cell proliferation as well as cell invasion. Mechanistically, overexpression of Bmal1 induces G2/M cell cycle arrest $[22,24]$. Baek and colleagues have demonstrated that ROR $\alpha$ is downregulated in breast cancer [19]. They also found a reduction of $\operatorname{ROR} \alpha$ phosphorylation in human colorectal tissues [29]. Moreover, $\mathrm{Xu}$ and colleagues have demonstrated that $\mathrm{ROR} \alpha$ suppresses breast tumor proliferation and invasion [30].

In this study, we have demonstrated that MLN4924 decreases the ubiquitination of $\operatorname{ROR} \alpha$ and subsequently its degradation in osteosarcoma cells. Although p21 is transcriptionally regulated by $\operatorname{ROR} \alpha$, and $\mathrm{p} 21$ was indeed upregulated after MLN4924 treatment in U2OS osteosarcoma cells, p21 does not seem to play a significant role in the effect of MLN4924 in U2OS cells. Nevertheless, p21 may play a role in the effect of MLN4924 in MG63 and SaoS-2 osteosarcoma cells, considering that MLN4924 induced apoptosis in MG63 and SaoS-2, but not in U2OS cells.

We have further demonstrated that Bmal1, another transcriptional target of $\operatorname{ROR} \alpha$, plays a critical role in MLN4924-induced cell growth suppression. Bmal1 is able to transactivate Wee1, which may in turn inhibit cyclin $\mathrm{B} / \mathrm{CDK} 1$ to halt cells at $\mathrm{G} 2 / \mathrm{M}$ cell cycle [31]. Indeed, MLN4924 significantly upregulated Wee1 and RNAi of ROR $\alpha$ led to significant reduction in Weel (Supplementary Figure S3).

In summary, this study provides a rationale for clinical trials of MLN4924 in osteosarcoma. Our data indicate an important role of circadian clock in the anticancer effect of MLN4924 in osteosarcoma cells. As ROR $\alpha$ and Bmall oscillate in a circadian manner, it will be intriguing to determine if the effect of MLN4924 is dependent on the circadian rhythm.

\section{MATERIALS AND METHODS}

\section{Cell culture}

Human osteosarcoma cell lines (U2OS, MG63 and Saos-2) were grown at $37{ }^{\circ} \mathrm{C}$ under $5 \% \mathrm{CO}_{2}$ in Dulbecco's modified Eagle medium (DMEM) supplemented with 10\% fetal bovine serum (FBS) and $100 \mathrm{U} / \mathrm{mL}$ of penicillin/ streptomycin.

\section{Antibodies and reagents}

Antibodies against Bmall (sc-8550) and ROR $\alpha$ (sc-28612) were obtained from Santa Cruz Biotechnology. Antibodies against Flag tag (M2, A2220) and Wee1 (SAB4503088) were from Sigma. Antibodies against HA tag (C29F4) and p21 (2947S) were from Cell Signaling Technology. MLN4924 was purchased from Med Chem Express. Cycloheximide (CHX), dexamethasone (DEX), Trizol, methylthiazolyldiphenyl-tetrazolium bromide (MTT) and propidium iodide (PI) were purchased from Sigma.

\section{Tumor xenografts in mice}

Nude mice at 4-6 weeks of age were purchased from SLAC Animal Center (Shanghai, China). MG63 cells $\left(1 \times 10^{6}\right.$ in $200 \mu \mathrm{L}$ of PBS) were injected subcutaneously near the scapula of the nude mice. 10 days after injection, the mice were randomly separated into two groups that received MLN4924 (30 mg/kg) or vehicle via intraperitoneal (i.p.) injection (twice a day for 3 days followed by no treatment for 2 days). Mice were euthanized after 15 days of the treatment and tumors were weighted. All animals were housed and handled in accordance with the institutional guide for the care and use of laboratory animals.

\section{RNA interference}

The target sequences for the siRNAs against ROR $\alpha$, Bmal1, p21 and negative control (Control) siRNA were as following:

ROR $\alpha$-siRNA-1: 5'- GCCAAACGCAUUGAUGG

AUTT -3';

ROR $\alpha$-siRNA-2: 5'- GGAGUUGUUCACUUCAG

AATT $-3^{\prime}$;

Bmal1-siRNA-1: 5'- GGCCUUCAGUAAAGGUU

GATT -3';

Bmal1-siRNA-2: 5'- GGUGAAAUCUAUGGAAU

AUTT-3';

p21-siRNA-1: 5' - GAUGGAACUUCGACUUU

GUTT-3';

p21-siRNA-2: 5'-CCUCUGGCAUUAGAAUU

AUTT-3'.

Control: 5' - UUCUCCGAACGUGCACGUTT -3'. All siRNAs were purchased from Gene Pharma (Suzhou, China). 


\section{Analysis of protein stability}

U2OS cells were transfected with plasmids expressing Bmall or Flag-ROR $\alpha$ using Lipofectamine 2000 reagent according to the manufacturer's protocol. At $48 \mathrm{~h}$ after transfection, cells were incubated with $0.1 \mathrm{mg} / \mathrm{mL}$ cycloheximide (CHX) to inhibit protein synthesis. Cells were lysed with $2 \%$ SDS buffer ( $2 \%$ SDS, $150 \mathrm{mM} \mathrm{NaCl}, 10 \mathrm{mM}$ Tris-HCl, pH 8.0, PMSF and protease inhibitor cocktail) at $0,3,6,9$ and $12 \mathrm{~h}$ after CHX treatment. Equal amounts of whole cell lysates were analyzed by Western blot with respective antibodies.

\section{Immunoprecipitation}

U2OS cells were transfected with plasmids expressing Bmal1 or Flag-ROR $\alpha$ and HA-tagged ubiquitin. After treatment, cells were lysed in 2\% SDS buffer and boiled for $10 \mathrm{~min}$ followed by sonication. Lysates were diluted 1:10 in dilution buffer (10 mM Tris- $\mathrm{HCl}, \mathrm{pH} 8.0$, $150 \mathrm{mM} \mathrm{NaCl}, 2 \mathrm{mM}$ EDTA, 1\% Triton X-100), incubated at $4{ }^{\circ} \mathrm{C}$ for $1 \mathrm{~h}$ with rotation and centrifuged at $13000 \mathrm{~g}$ for $30 \mathrm{~min}$. $500 \mu \mathrm{g}$ of cell lysates were incubated with $1 \mu \mathrm{g}$ of antibody with constant agitation overnight at $4{ }^{\circ} \mathrm{C}$. Then, $30 \mu \mathrm{L}$ of protein-A agarose bead slurry was added to pull down the immune-complexes. Immunoprecipitated proteins were washed with washing buffer $(10 \mathrm{mM}$ Tris$\mathrm{HCl}, \mathrm{pH}$ 8.0, $1 \mathrm{M} \mathrm{NaCl}, 1 \mathrm{mM}$ EDTA, 1\% NP-40). After boiling with $2 \times$ SDS loading buffer, the protein samples were analyzed by Western blot with respective antibodies.

\section{Real-time quantitative PCR (qPCR)}

Total RNA was extracted using Trizol reagent according to the manufacturer's instruction. $2 \mu \mathrm{g}$ of total RNA were reverse-transcribed using the RevertAid First Strand cDNA Synthesis Kit (Fermentas). The mRNA levels were examined with qPCR using $1 \times$ SYBR Green PCR master mix (Fermentas) by C1000 touch Thermal Cycler (Bio-Rad). The primers were as following:

Actin-Forward: 5'-GGCATGGGTCAGAAGGATT-3'; Actin-Reverse: 5'-TGGTGCCAGATTTTCTCCA-3';

Bmal1-Forward: 5'-CCAAGAAAGTATGGACACA GACAAA-3';

Bmall-Reverse: 5'-GCATTCTTGATCCTTCCTTG GT-3';

ROR $\alpha$-Forward: 5'-CAGGCTTCTTTCCCTACTGT TCGT-3';

ROR $\alpha$-Reverse: 5'-CCGCTGCTTGTTTTGATAGT TCTC-3'.

\section{MTT assay}

Cells were transfected with siRNAs targeting ROR $\alpha$, Bmal1 or p21, respectively. $24 \mathrm{~h}$ after transfection, cells were seeded in 96 well plates at the density of $1 \times 10^{3}$ cells per well and incubated with
MLN4924 $(3 \mu \mathrm{M})$. After various times, the cells were stained with $20 \mu \mathrm{L}$ of sterile MTT dye $(5 \mathrm{mg} / \mathrm{mL})$ for $4 \mathrm{~h}$ at $37^{\circ} \mathrm{C}$ followed by removal of the culture medium and the addition of $200 \mu \mathrm{L}$ of DMSO. The absorbance at $570 \mathrm{~nm}$ was measured and the absorbance at $630 \mathrm{~nm}$ was used as a reference. All assays were conducted at least three times and performed in triplicate on different days using different batches of cells.

\section{Flow cytometry}

After treatment, cells were harvested and washed with cold PBS and fixed in ice-cold $70 \%$ ethanol overnight at $-20{ }^{\circ} \mathrm{C}$, The fixed cells were incubated with $100 \mu \mathrm{L}$ of propidium iodide (PI, $50 \mu \mathrm{g} / \mathrm{mL}$ ) for $30 \mathrm{~min}$ at $4{ }^{\circ} \mathrm{C}$ in the dark. At least 10,000 cells were analyzed of the cell cycle using a Cytomics FC 500 instrument (Beckman Coulter) equipped with CXP software. To analyze apoptosis, cells were stained with Annexin V-FITC/PI, and apoptotic cells were examined by flow cytometry.

\section{Statistical analysis}

All statistical analyses were performed using the Prism 6.01 (Graph Pad Software, San Diego, CA). Statistically significant differences between groups were determined by a repeated ANOVA followed by unpaired $t$ test.

\section{CONFLICTS OF INTEREST}

No potential conflicts of interest were disclosed.

\section{GRANT SUPPORT}

This work was supported by the National Basic Research Program of China (2012CB517904), the National Natural Science Foundation of China (31371187), the Lotus Scholar Professorship Funds from Hunan Province Government and a research grant provided by the Central South University of China (2014zzts064).

\section{REFERENCES}

1. Isakoff MS, Bielack SS, Meltzer P and Gorlick R. Osteosarcoma: Current Treatment and a Collaborative Pathway to Success. J Clin Oncol. 2015; 33:3029-3035.

2. Tang QL, Xie XB, Wang J, Chen Q, Han AJ, Zou CY, Yin JQ, Liu DW, Liang Y, Zhao ZQ, Yong BC, Zhang RH, Feng QS, et al. Glycogen synthase kinase-3beta, NF-kappaB signaling, and tumorigenesis of human osteosarcoma. J Natl Cancer Inst. 2012; 104:749-763.

3. Liu HC, Enikolopov G and Chen Y. Cul4B regulates neural progenitor cell growth. BMC Neurosci. 2012; 13:112.

4. Shah JJ, Jakubowiak AJ, O'Connor OA, Orlowski RZ, Harvey RD, Smith MR, Lebovic D, Diefenbach C, Kelly K, Hua Z, Berger AJ, Mulligan G, Faessel HM, Tirrell S, Dezube 
BJ and Lonial S. Phase I Study of the Novel Investigational NEDD8-Activating Enzyme Inhibitor Pevonedistat (MLN4924) in Patients with Relapsed/Refractory Multiple Myeloma or Lymphoma. Clin Cancer Res. 2016; 22:34-43.

5. Soucy TA, Smith PG, Milhollen MA, Berger AJ, Gavin JM, Adhikari S, Brownell JE, Burke KE, Cardin DP, Critchley $\mathrm{S}$, Cullis CA, Doucette A, Garnsey JJ, et al. An inhibitor of NEDD8-activating enzyme as a new approach to treat cancer. Nature. 2009; 458:732-736.

6. Nawrocki ST, Griffin P, Kelly KR and Carew JS. MLN4924: a novel first-in-class inhibitor of NEDD8-activating enzyme for cancer therapy. Expert Opin Investig Drugs. 2012; 21:1563-1573.

7. Khalife J, Radomska HS, Santhanam R, Huang X, Neviani P, Saultz J, Wang H, Wu YZ, Alachkar H, Anghelina M, Dorrance A, Curfman J, Bloomfield CD, et al. Pharmacological targeting of miR-155 via the NEDD8activating enzyme inhibitor MLN4924 (Pevonedistat) in FLT3-ITD acute myeloid leukemia. Leukemia. 2015; 29:1981-1992.

8. Visconte V, Nawrocki ST, Espitia CM, Kelly KR, Possemato A, Beausoleil SA, Han Y, Carraway HE, Nazha A, Advani AS, Maciejewski JP, Sekeres MA and Carew JS. Comprehensive quantitative proteomic profiling of the pharmacodynamic changes induced by MLN4924 in acute myeloid leukemia cells establishes rationale for its combination with azacitidine. Leukemia. 2015.

9. Chen P, Hu T, Liang Y, Jiang Y, Pan Y, Li C, Zhang P, Wei D, Li P, Jeong LS, Chu Y, Qi H, Yang M, Hoffman RM, Dong $\mathrm{Z}$ and Jia L. Synergistic inhibition of autophagy and neddylation pathways as a novel therapeutic approach for targeting liver cancer. Oncotarget. 2015; 6:9002-9017. doi: 10.18632/oncotarget.3282.

10. Kuo KL, Ho IL, Shi CS, Wu JT, Lin WC, Tsai YC, Chang HC, Chou CT, Hsu CH, Hsieh JT, Chang SC, Pu YS and Huang KH. MLN4924, a novel protein neddylation inhibitor, suppresses proliferation and migration of human urothelial carcinoma: In vitro and in vivo studies. Cancer Lett. 2015; 363:127-136.

11. Ho IL, Kuo KL, Liu SH, Chang HC, Hsieh JT, Wu JT, Chiang CK, Lin WC, Tsai YC, Chou CT, Hsu CH, Pu YS, Shi CS and Huang KH. MLN4924 Synergistically Enhances Cisplatin-induced Cytotoxicity via JNK and Bcl-xL Pathways in Human Urothelial Carcinoma. Sci Rep. 2015; 5:16948.

12. Nawrocki ST, Kelly KR, Smith PG, Espitia CM, Possemato A, Beausoleil SA, Milhollen M, Blakemore S, Thomas M, Berger A and Carew JS. Disrupting protein NEDDylation with MLN4924 is a novel strategy to target cisplatin resistance in ovarian cancer. Clin Cancer Res. 2013; 19:3577-3590.

13. Pan WW, Zhou JJ, Yu C, Xu Y, Guo LJ, Zhang HY, Zhou D, Song FZ and Fan HY. Ubiquitin E3 ligase CRL4(CDT2/ DCAF2) as a potential chemotherapeutic target for ovarian surface epithelial cancer. J Biol Chem. 2013; 288:29680-29691.
14. Jia L, Li H and Sun Y. Induction of p21-dependent senescence by an NAE inhibitor, MLN4924, as a mechanism of growth suppression. Neoplasia. 2011; 13:561-569.

15. Gu Y, Kaufman JL, Bernal L, Torre C, Matulis SM, Harvey RD, Chen J, Sun SY, Boise LH and Lonial S. MLN4924, an NAE inhibitor, suppresses AKT and mTOR signaling via upregulation of REDD1 in human myeloma cells. Blood. 2014; 123:3269-3276.

16. Lin JJ, Milhollen MA, Smith PG, Narayanan U and Dutta A. NEDD8-targeting drug MLN4924 elicits DNA rereplication by stabilizing Cdt1 in $\mathrm{S}$ phase, triggering checkpoint activation, apoptosis, and senescence in cancer cells. Cancer Res. 2010; 70:10310-10320.

17. Bailly A, Perrin A, Bou Malhab LJ, Pion E, Larance M, Nagala M, Smith P, O’Donohue MF, Gleizes PE, Zomerdijk J, Lamond AI and Xirodimas DP. The NEDD8 inhibitor MLN4924 increases the size of the nucleolus and activates p53 through the ribosomal-Mdm2 pathway. Oncogene. 2016; 35:415-426.

18. Kojetin DJ and Burris TP. REV-ERB and ROR nuclear receptors as drug targets. Nat Rev Drug Discov. 2014; 13:197-216.

19. Lee JM, Lee JS, Kim H, Kim K, Park H, Kim JY, Lee SH, Kim IS, Kim J, Lee M, Chung CH, Seo SB, Yoon JB, et al. EZH2 generates a methyl degron that is recognized by the DCAF1/DDB1/CUL4 E3 ubiquitin ligase complex. Mol Cell. 2012; 48:572-586.

20. Kim H, Lee JM, Lee G, Bhin J, Oh SK, Kim K, Pyo KE, Lee JS, Yim HY, Kim KI, Hwang D, Chung J and Baek SH. DNA damage-induced RORalpha is crucial for p53 stabilization and increased apoptosis. Mol Cell. 2011; 44:797-810.

21. Jiang W, Zhao S, Jiang X, Zhang E, Hu G, Hu B, Zheng P, Xiao J, Lu Z, Lu Y, Ni J, Chen C, Wang X, Yang L and Wan $\mathrm{R}$. The circadian clock gene Bmal1 acts as a potential antioncogene in pancreatic cancer by activating the p53 tumor suppressor pathway. Cancer Lett. 2016; 371:314-325.

22. Jung CH, Kim EM, Park JK, Hwang SG, Moon SK, Kim WJ and Um HD. Bmall suppresses cancer cell invasion by blocking the phosphoinositide 3-kinase-Akt-MMP-2 signaling pathway. Oncol Rep. 2013; 29:2109-2113.

23. Khapre RV, Kondratova AA, Susova O and Kondratov RV. Circadian clock protein BMAL1 regulates cellular senescence in vivo. Cell Cycle. 2011; 10:4162-4169.

24. Zeng ZL, Luo HY, Yang J, Wu WJ, Chen DL, Huang P and $\mathrm{Xu}$ RH. Overexpression of the circadian clock gene Bmall increases sensitivity to oxaliplatin in colorectal cancer. Clin Cancer Res. 2014; 20:1042-1052.

25. Hansen J. Risk of breast cancer after night- and shift work: current evidence and ongoing studies in Denmark. Cancer Causes Control. 2006; 17:531-537.

26. Kolstad HA. Nightshift work and risk of breast cancer and other cancers--a critical review of the epidemiologic evidence. Scand J Work Environ Health. 2008; 34:5-22. 
27. Lee S, Donehower LA, Herron AJ, Moore DD and Fu L. Disrupting circadian homeostasis of sympathetic signaling promotes tumor development in mice. PLoS One. 2010; 5:e10995.

28. Taniguchi H, Fernandez AF, Setien F, Ropero S, Ballestar E, Villanueva A, Yamamoto H, Imai K, Shinomura Y and Esteller M. Epigenetic inactivation of the circadian clock gene BMAL1 in hematologic malignancies. Cancer Res. 2009; 69:8447-8454.

29. Lee JM, Kim IS, Kim H, Lee JS, Kim K, Yim HY, Jeong J, Kim JH, Kim JY, Lee H, Seo SB, Kim H, Rosenfeld MG,
Kim KI and Baek SH. RORalpha attenuates Wnt/betacatenin signaling by PKCalpha-dependent phosphorylation in colon cancer. Mol Cell. 2010; 37:183-195.

30. Xiong G, Wang C, Evers BM, Zhou BP and Xu R. RORalpha suppresses breast tumor invasion by inducing SEMA3F expression. Cancer Res. 2012; 72:1728-1739.

31. Visconti R, Della Monica R, Palazzo L, D'Alessio F, Raia M, Improta S, Villa MR, Del Vecchio L and Grieco D. The Fcp1-Wee1-Cdk1 axis affects spindle assembly checkpoint robustness and sensitivity to antimicrotubule cancer drugs. Cell Death Differ. 2015; 22:1551-1560. 